\title{
Effects of dielectric barrier discharge (DBD) generated plasma on microbial reduction and quality parameters of fresh mackerel (Scomber scombrus) fillets
}

\author{
I. Albertos $^{\mathrm{a}, *}$, A.B. Martín-Diana ${ }^{\mathrm{a}, *}$, P.J. Cullen ${ }^{\mathrm{b}}$, B.K. Tiwari ${ }^{\mathrm{c}}$, S.K. Ojha ${ }^{\mathrm{c}}$, P. Bourke ${ }^{\mathrm{b}}$, C. Álvarez ${ }^{\mathrm{c}}$, \\ D. Rico ${ }^{\mathrm{a}}$
}

a Agrarian Technological Institute of Castilla and Leon (ITACyL). Ctra. Burgos Km 119, Finca Zamadueñas, 47071 Valladolid, Spain

b School of Food Science \& Environmental Health, Dublin Institute of Technology, Dublin, Ireland

${ }^{c}$ Teagasc Food Research Centre, Ashtown, Dublin 15, Ireland

A R T I C L E I N F O

\section{Keywords:}

Dielectric barrier discharge

Cold atmospheric plasma

Atlantic mackerel

Shelf life

Quality

Oxidative parameters

\begin{abstract}
A B S T R A C T
The effect of atmospheric cold plasma generated by a novel in-package dielectric barrier discharge (DBD) on microbial and quality parameters of mackerel fillets was investigated. DBD voltage $(70 \mathrm{kV}$ and $80 \mathrm{kV})$ and treatment time (1, 3 and $5 \mathrm{~min}$ ) were studied. Within $24 \mathrm{~h}$ of DBD treatment, spoilage bacteria (total aerobic psychrotrophic, Pseudomonas and lactic acid bacteria) were significantly reduced. However, significant effects on lipid oxidation parameters (PV, Dienes) were observed for the treated samples. Both studied treatment factors, treatment voltage and time, significantly affected anti-microbial efficacy and lipid oxidation. Nevertheless, no changes in $\mathrm{pH}$ or colour (except for $\mathrm{L}^{*}$ ) were observed. These results suggest atmospheric cold plasma generated by DBD could be implemented as technology for fish processing, retaining product quality over its shelf life. However, further investigations are needed in order to implement this technology and to control and mitigate its limitations, mainly associated to increased oxidation.

Industrial relevance: Cold atmospheric plasma (CAP) has gained attention as an emerging and non termal technology for decontamination of food. This technology has been used on fruits and vegetables successfully for the inactivation of food-borne pathogens. However, this technology has not been investigated in fish, being a highly persibale product.

The use of dielectric barrier discharge (DBD) to produce cold plasma showed a potential industrial application at low cost and convenience. Cold plasma was found to be effective for reducing the main problem of oily fish quality such as the spoilage bacteria. However, this technology seems to accelerate oxidative pathways; for this reason, further studies to investigate the use of antioxidants in combination with cold plasma as "hurdle technology" to minimise this negative effect are suggested.
\end{abstract}

\section{Introduction}

Several research works have identified the potential of atmospheric cold plasma for decontamination of foods. The term "plasma" refers to a partially or wholly ionised gas. Nonthermal or cold plasmas are considered to be in a state of nonthermal equilibrium (Schlüter et al., 2013; Surowsky, Schlüter, \& Knorr, 2015). Although they contain high temperature electrons, the neutrals, ions, and radicals remain close to room temperature and as such they are considered cold plasmas with limited macro heating of material to which they interface with (Misra et al., 2015; Mishra, Bathia, Pal, Visen, \& Trivedi, 2016; Min et al., 2017). Cold plasma may be generated by a diversity of electrical discharges such as DC glow discharge, radio frequency (RF) discharge, dielectric barrier discharge (DBD), atmospheric pressure plasma jet (APPJ), microwave and pulsed power discharge.

Industrially cold atmospheric plasma equipment has not implemented in food industry for direct food contact but is employed for packaging and label modification. The main limitation is the necessity of working under vacuum and thus incompatible with food processing (Misra, Keener, Bourke, Mosnier, \& Cullen, 2014). Experimentally plasma jet and dielectric barrier discharges (DBD) have been studied. Plasma jet typically operate with noble gases (Misra, Tiwari, Raghavarao, \& Cullen, 2011), which increase the cost of treatment. Ideally, ambient air would be use in the cold plasma technology in

\footnotetext{
* Corresponding authors.

E-mail addresses: albmunir@itacyl.es (I. Albertos), mardiaan@itacyl.es (A.B. Martín-Diana).
} 


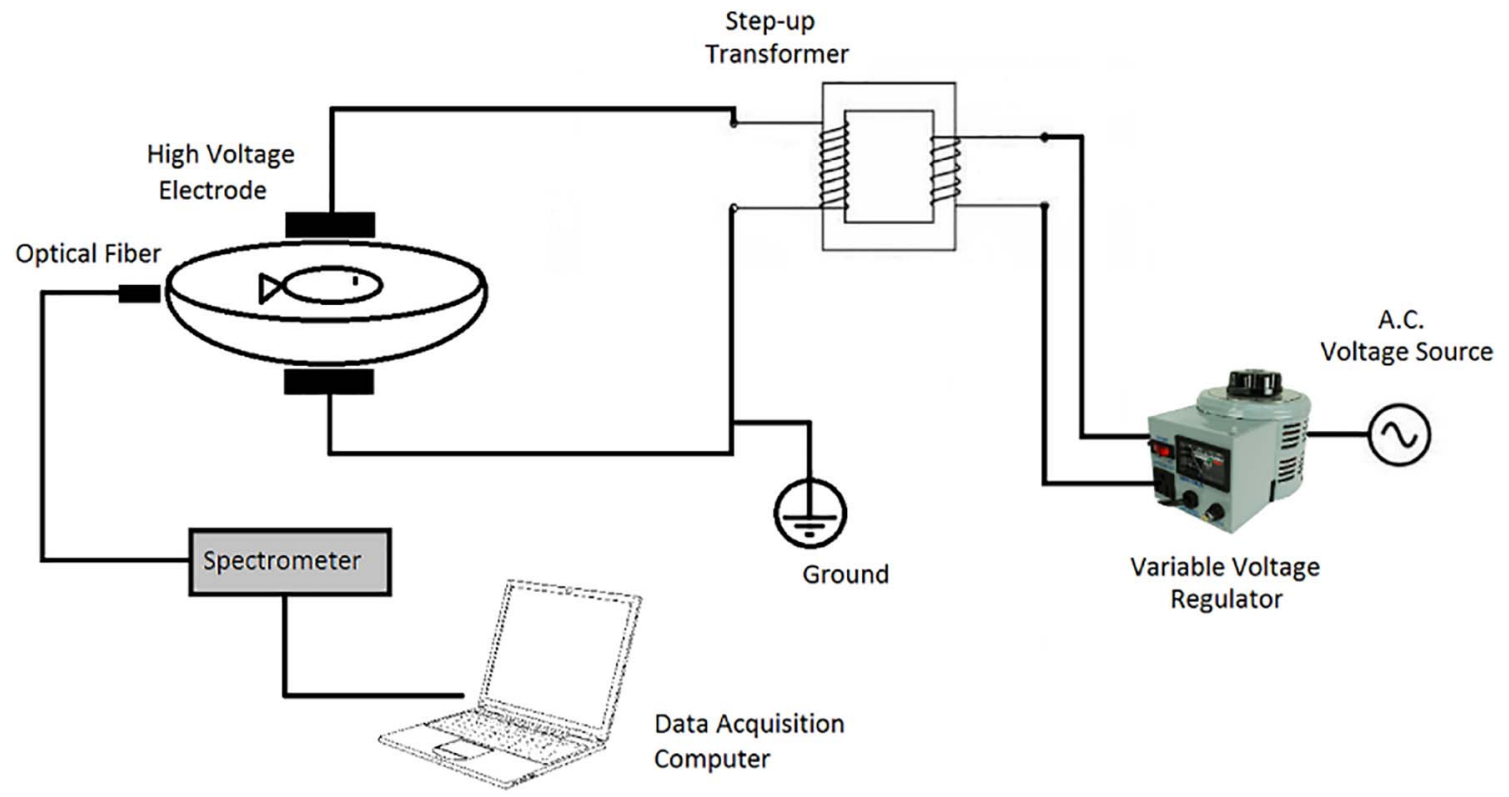

Fig. 1. Schematic of the experimental set-up for DBD of Atlantic mackerel fillets.

order for food industry to implement this technology. In this sense, previous studies have demonstrated the application of dielectric barrier discharges to generate atmospheric cold plasma inside sealed packages filled with air through the application of sufficiently high voltages (Misra, Keener, et al., 2014; Misra, Patil, et al., 2014; Misra, Ziuzina, Cullen, \& Keener, 2013; Pankaj, Misra, \& Cullen, 2013). Dielectric barrier discharges are generated when high voltage is applied across the electrodes. These discharges generate energetic electrons that dissociate oxygen molecules by direct impact. This single $\mathrm{O}$ atom combines with oxygen molecules $\left(\mathrm{O}_{2}\right)$ to form ozone gas (Misra, Keener, et al., 2014; Misra, Patil, et al., 2014). Another advantage, in comparison with other cold plasma's generators, is the treatment takes place inside sealed packages, which eliminates the risk of post-process contamination and facilitates rapid treatment times as the resultant reactive species are contained within the package and continue to act post treatment (Misra, Keener, et al., 2014; Misra, Patil, et al., 2014).

Dielectric barrier discharges have successfully applied on food retaining food quality in dry products such as wheat flour (Misra et al., 2015), legumes such as peas (Bußler et al., 2015), dried laver (Kim, Puligundla, \& Mok, 2015) or vegetables such as tomatoes (Pankaj et al., 2013; Misra, Keener, et al., 2014; Misra, Patil, et al., 2014), spinach (Klockow \& Keener, 2009) and fruits such as strawberries (Misra, Keener, et al., 2014; Misra, Patil, et al., 2014), grapes (Moon, Noh, Moon, \& You, 2016), fresh-cut melon (Tappi et al., 2015) and orange juice (Almeida et al., 2015).

The activity of microorganism is the main factor limiting the shelf life in fresh fish (Ólafsdóttir et al., 1997). However, there are no available studies concerning the effects of cold plasma on the spoilage microbiology and quality of fish. Plasma sources for decontamination of foodstuff such as meat, have been reported (Kim, Yong, Park, Choe, \& Jo, 2013; Kim et al., 2011; Noriega, Shama, Laca, Díaz, \& Kong, 2011; Rød, Hansen, Leipold, \& Knøchel, 2012). However, the suitability of ACP for high lipid containing food is doubted. These products are susceptible to detrimental effects of oxidation due to the formation of hydroxyl acids, keto acids, short-chain acids and aldehydes (Misra et al., 2011). The effect of ACP on food quality parameters in meat products has not been studied extensively. Further studies should be conducted to clarify these results. Kim et al. (2011) did not find any significant changes due to plasma jet treatment ( $\mathrm{pH}$, TBARS, microscopic observation) except for colour, mainly $L^{*}$ values of the meat surface was increased. Rød et al. (2012) demonstrated that TBARS values of plasma treated samples increased with power and storage time but that the plasma did not induce measurable colour differences. Kim et al. (2013) found lower TBARS values in plasma treated bacon than the control upon treatment, but increased subsequently as a function of storage. Also, significant reductions in the sensory quality parameters were observed in plasma treated samples. There are few reports of DBD treatment on meat products. Jayasena et al. (2015) observed minor deterioration of fresh pork and beef quality. Only high exposure time $(10 \mathrm{~min})$ caused lipid oxidation. Furthermore colorimetric measures showed that $L^{*}$ was not affected by DBD, whereas a* values were lowered significantly after 5 and $7.5 \mathrm{~min}$ of DBD exposure. Wang, Zhuang, and Zhang (2016) demonstrated that DBD was effective in inhibiting spoilage bacteria for inoculated chicken carcasses.

The objectives of this study were to investigate the effects of different conditions (voltages and times) for DBD on the treatment of fish spoilage bacteria, and how this affects lipid oxidation and the physicochemical characteristics of Atlantic mackerel fillets.

\section{Material and methods}

\subsection{Chemicals}

All the chemicals were analytical grade obtained from SigmaAldrich (Wicklow, Ireland). All the solvents were HPLC grade and also purchased from Sigma-Aldrich (Wicklow, Ireland). Culture media were supplied by Oxoid (Basingstoke, UK).

\subsection{Product characteristics}

Six kilos of Atlantic mackerel (Scomber scombrus) caught in early February 2015 were purchased in Stevie Connolly Seafood (Dublin, Ireland). The average weight for each fillet was $100 \mathrm{~g}$.

\subsection{In-package plasma treatment}

Two fillets were packaged in commercial $270 \mu \mathrm{m}$-thick polyethylene terephthalate trays $(150 \mathrm{~mm} \times 70 \mathrm{~mm} \times 35 \mathrm{~mm})$ and sealed with a high barrier-50 $\mu \mathrm{m}$ film. A plasma discharge was generated inside the trays using dielectric set-up, as shown in Fig. 1. The package was placed between two circular aluminium plate electrodes (outer diameter $=158 \mathrm{~mm}$ ) with a contact surface area of $249.64 \mathrm{~cm}^{2}$. A $2 \mathrm{~mm}$ thick 
polypropylene sheet was used to stabilize the discharge. The electrode separation was adjusted to the tray height of $35 \mathrm{~mm}$. The applied voltage to the electrode was controlled using a set-up transformer (Phoenix Technologies, Inc., USA) at a fixed frequency of $50 \mathrm{~Hz}$, the input to which is regulated using a variable transformer. The samples were treated in triplicate at two discrete voltages of 70 and $80 \mathrm{kV}$ for different treatment times (1, 3 and $5 \mathrm{~min}$ ). The experiment was performed in duplicate. The atmospheric air conditions at the time of treatment were $15{ }^{\circ} \mathrm{C}$ and $50 \%$ relative humidity, measured using a humiditytemperature probe connected to a data logger (Testo 176T2, Testo Ltd., UK). Control and treated packages were stored at $4{ }^{\circ} \mathrm{C}$. In order to maximize antimicrobial efficacy of the treatment, samples were stored for 24-h, allowing interaction of the metastable reactive species with the product and subsequent reaction or reversion of the reactive species to the original gas composition (Ziuzina, Patil, Cullen, Keener, \& Bourke, 2013; Misra et al., 2013).

\subsection{Effect of cold plasma on microbiological growth}

Fish samples $(10 \mathrm{~g})$ were aseptically transferred into bags (Seward 80 bags, United Kingdom) with $90 \mathrm{~mL}$ of sterile maximum recovery diluent (MRD) and homogenised with a Stomacher blender for $5 \mathrm{~min}$ (Seward, London, UK). For each sample, appropriate serial decimal dilutions were prepared in MRD for the following microorganism counts:

(i) Total aerobic mesophilic bacteria were determined using Tryptic Glucose Yeast Agar (PCA) with $1 \% \mathrm{NaCL}$ after incubation at $30{ }^{\circ} \mathrm{C}$ for $72 \mathrm{~h}$.

(ii) Total aerobic psychrotrophic bacteria on $1 \% \mathrm{NaCl}$ PCA spread plates, incubated at $15^{\circ} \mathrm{C}$ for $72 \mathrm{~h}$.

(iii) Lactic acid bacteria (LAB) on double-layer Man Rogosa Sharpe medium incubated at $30{ }^{\circ} \mathrm{C}$ for $72 \mathrm{~h}$.

(iv) Pseudomonas on spread plates of Pseudomonas Agar Base with added CFC (Cetrimide, Fucidine, Cephalosporine) supplement for Pseudomonas spp. incubated at $25^{\circ} \mathrm{C}$ for $48 \mathrm{~h}$.

\subsection{Effect of cold plasma on physicochemical parameters}

\subsection{1. $p H$}

The $\mathrm{pH}$ of fillets was measured at room temperature using a portable pH meter (Orion Research Inc., Boston, MA 02129, USA).

\subsubsection{Proximate composition}

Moisture content was gravimetrically determined according to AOAC (1995). Total lipids were extracted from 10-g samples with methanol/chloroform (1:1, v:v) according to the Bligh and Dyer (1959).

\subsection{Effect of cold plasma on lipid oxidation}

\subsubsection{Fatty acid composition (FA)}

The fatty acid profile of the samples was determined in triplicate from the Bligh \& Dyer extracts. The lipid-containing chloroform phase was separated and evaporated to dryness under nitrogen. The remaining residue was dissolved in $1 \mathrm{~mL}$ of hexane and a methylation procedure carried out by adding $100 \mu \mathrm{L}$ of $0.5 \mathrm{M}$ methanolic $\mathrm{KOH}$ and leaving the reaction for $10 \mathrm{~min}$ at room temperature (RT). The upper layer was transferred to a 2-mL vial. Analysis of fatty acid methyl esters (FAME) were carried out on a gas chromatograph Agilent 7890A (Agilent Technologies, PA, California, USA) equipped with a DB-23 column $\quad 60 \mathrm{~m} \times 0.32 \mathrm{~mm}, \quad(0.25 \mu \mathrm{m} \quad$ film thickness) (Agilent Technologies, Palo Alto, CA, USA) and a flame ionisation detector. Helium was used as the carrier gas. The oven temperature was programmed to $50{ }^{\circ} \mathrm{C}$ for the first $7 \mathrm{~min}$ and increased to $200{ }^{\circ} \mathrm{C}$ at a rate of $25^{\circ} \mathrm{C} / \mathrm{min}$; then, the temperature was increased to $230^{\circ} \mathrm{C}$ at a rate of $3{ }^{\circ} \mathrm{C} / \mathrm{min}$ and held for $26 \mathrm{~min}$. Injector and detector temperatures were $250{ }^{\circ} \mathrm{C}$ and $280^{\circ} \mathrm{C}$, respectively. One $\mu \mathrm{L}$ of the hexane extract was injected in split mode (ratio 25:1), and FAMEs were identified by comparison of retention times with those of 37 FAME's standard mix (Supelco, Sigma Aldrich, CO). Polyene ratio was calculated on the basis of fatty acid composition, being $([20: 5]+[22: 6]) 100 /[16: 0]$. The ratio $\omega 6 / \omega 3$ was also estimated.

\subsubsection{Peroxide value (PV)}

PV was measured directly on the Bligh \& Dyer extract according to the method described by the International IDF Standards (1991). Results were expressed in milliequivalents of $\mathrm{O}_{2}$ per kilogram of oil.

\subsubsection{Conjugated hydroperoxides (Dienes)}

Conjugated hydroperoxides were measured on the Bligh and Dyer extract dissolved in hexane, as described by Undeland, Stading, and Lingnert (1998). The absorbance was measured at $268 \mathrm{~nm}$ and results were calculated as mmoles of hydroperoxides per kilogram of oil.

\subsubsection{Thiobarbituric acid reactives substances (TBARS)}

Samples were analysed using the methodology described by Vyncke (1975) on a 5\% trichloracetic acid extract of the restructured fish muscle. Results were expressed as mg of malondialdehyde (MDA) per kilogram of fish.

\subsection{Effect of cold plasma on colour}

The colour parameters lightness $\left(\mathrm{L}^{*}\right)$, redness (a*) and yellowness $(b *)$ were measured using a colourimeter (Colour Quest XE Hunter Lab, Northants, UK). The illuminant was D65 (colour temperature of $6504 \mathrm{~K}$ ) and the standard observer was $10^{\circ}$. The colourimeter was standardised using a light trap and a white calibration plate. Measurements were taken on the samples packaged in transparent plastic bags at three different points.

\subsection{Effect of cold plasma on protein structure and water distribution}

\subsubsection{Nuclear magnetic resonance (NMR) measurement}

Ten grams of mackerel were placed in sealed NMR tubes and held at $25^{\circ} \mathrm{C}$ in a water bath for $1 \mathrm{~h}$. NMR data were generated using a Mara Ultra Instrument (Oxford Instruments, Abington, UK) with a resonance frequency of 23.2 MHz. Transverse measurements $\left(\mathrm{T}_{2}\right)$ were conducted using the Carr-Purcell-Meiboom-Gill (CPMG) pulse sequence with the resultant relaxation decays analysed by tri-exponential unsupervised fitting in the RI Win-DXP software (version 1.2.3; Oxford Instruments).

\subsection{Statistical analysis}

The data were subjected to One-way ANOVA. Fisher LSD (Least Significant Difference) test was applied for determining group differences at 95\% confidence level. Statgraphics Centurion XVI was used for carrying out the statistical analysis.

\section{Results \& discussion}

\subsection{Effect of cold plasma on microbiological growth}

Fig. 2 shows the changes in the microbial flora of Atlantic mackerel subjected to ACP. The initial total aerobic mesophilic bacteria (control) were $4.1 \pm 0.07 \log \mathrm{CFU} \mathrm{g}^{-1}$, which is comparable to values reported in the literature of between 3.0 and $5.0 \log \mathrm{CFU} \mathrm{g}^{-1}$ on filleted fish (Chytiri, Chouliara, Savvaidis, \& Kontominas, 2004; Dalgaard, Gram, \& Huss, 1993). There was no significant $(P>0.05)$ reduction in the total aerobic mesophilic count. However, psychrotrophic bacteria, $\mathrm{LAB}$ and Pseudomonas counts were significantly $(P<0.05)$ reduced due to DBD.

Total aerobic psychrotropic bacteria incubated at $15{ }^{\circ} \mathrm{C}$ were higher in Atlantic mackerel compared to total aerobic mesophilic bacteria. 


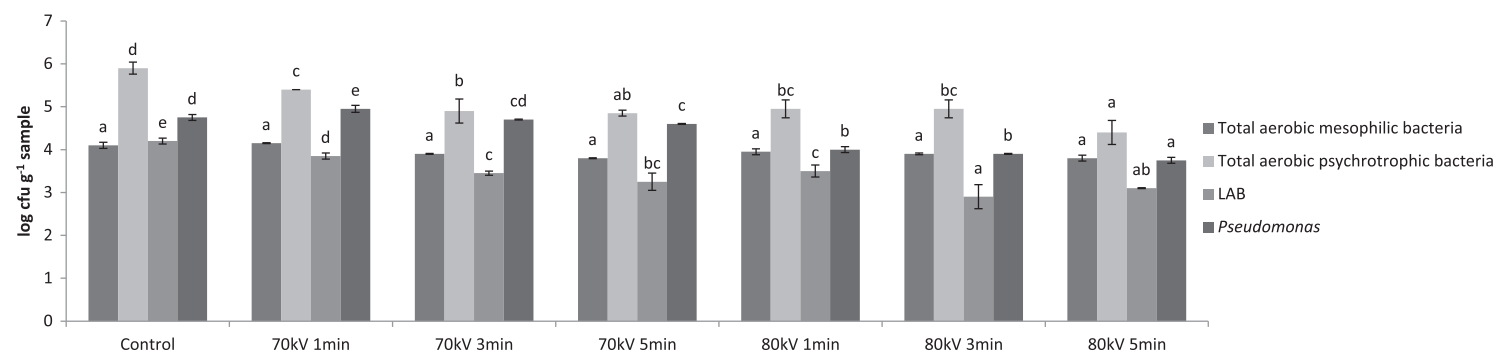

Fig. 2. Total aerobic mesophilic bacteria, psychrotrophic bacteria, LAB and Pseudomonas (log CFU g ${ }^{-1}$ samples) counts in Atlantic mackerel subjected to different DBD treatments. Different letters have mean values that are significantly different $(P<0.05)$ due to the treatment among the same microorganism.

Similarly, Núñez-Flores, Castro, López-Caballero, Montero, and GómezGuillén (2013) showed differences in the total microorganism counts depending upon the incubation temperature related to the nature of psychrotrophic microbiota predominant in fish. The reduction of total aerobic psychrotrophic bacteria was more dependent on plasma exposure time than on voltage applied. In any case, the most effective reduction was achieved using the highest voltage and time $(80 \mathrm{kV}$, 5 min).

LAB counts were lower than Pseudomonas counts. LAB were also found to be more dominant storage. This finding can be explained due to the inhibition of other bacteria by the formation of lactic acid and bacteriocins (Gram \& Dalgaard, 2002). Besides, LAB can grow under both anaerobic and aerobic conditions. Other authors found Pseudomonas to be the dominant microflora for filleted chilled fish (Chytiri et al., 2004). Both microorganisms (LAB and Pseudomonas) were found to display greater sensitivity to applied voltage than treatment time. Kim et al. (2011) studied the effect of atmospheric pressure plasma on inactivation of pathogens (L. monocytogenes, E. coli and S. typhimurium). Concerning LAB and Pseudomonas, the previous work along with the present study, demonstrated that plasma treatment at high voltage was effective for reducing fish spoilage microorganism over short time periods. Wang et al. (2016) demonstrated the effectiveness of DBD at $55 \mathrm{kV}$ for $3 \mathrm{~min}$ for inactivation of Pseudomonas fluorescens isolated from chicken carcasses and suspended in liquid media.

Ozone is one key metastable generated in large quantities by DBDs and which can be measured relatively easily inside of the package Wang et al. (2016) claimed that ozone is a relatively long half-life compared to other reactive species formed during discharge. Other reactive oxygen species (ROS) such as atomic oxygen $(\mathrm{O})$ and hydroxyl radicals $(\mathrm{OH})$ are also generated and they can react with almost all bacteria cell resulting in damage to DNA proteins, lipids and membranes (Kim et al., 2011; Kim et al., 2013). The prototype in-package system used in this study has previously been characterised using electrical and optical diagnostics (Moiseev et al., 2014). The post-discharge gas composition within the sealed packages was quantified using UV-Vis absorption spectroscopy. The concentration of ozone and nitrogen oxides $\mathrm{O}_{3}, \mathrm{NO}_{2}$, $\mathrm{NO}_{3}, \mathrm{~N}_{2} \mathrm{O}_{4}$ ) was found to increases with treatment time however a strong decrease in $\mathrm{O}_{3}$ levels was observed with increases in relative humidity. The decrease in $\mathrm{O}_{3}$ and an abundance of nitrogen oxides is ascribed to high specific power densities in the closed container and to increasing RH levels. Humid air large gap DBD plasmas in closed containers generate along with $\mathrm{O}_{3}$, high levels of nitrogen oxides and $\mathrm{HNOx}$ $(x=1,4)$ acids which can be linked to bactericidal effects.

\subsection{Effect of cold plasma on physicochemical parameters}

\subsection{1. $p H$}

The $\mathrm{pH}$ values were similar to values reported in the literature for Atlantic mackerel (Senturk \& Alpas, 2013). Atlantic mackerel did not show any clear trend in $\mathrm{pH}$ behaviour after plasma exposure (Fig. 3).

There were no differences on the $\mathrm{pH}$ levels of Atlantic mackerel after DBD treatments with the exception of $80 \mathrm{kV}$ at $5 \mathrm{~min}$. These results were consistent with Kim et al. (2011) and Ulbin-Figlewicz,

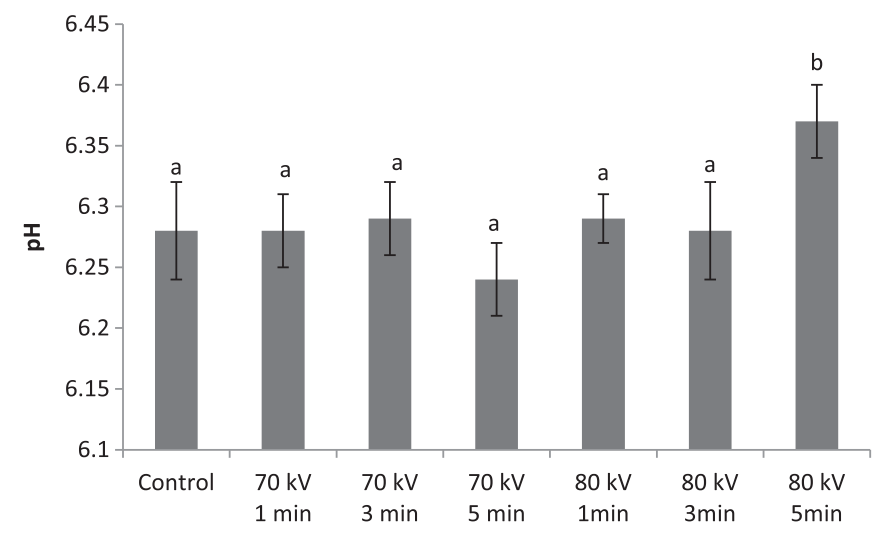

Fig. 3. $\mathrm{pH}$ of Atlantic mackerel fillets submitted different DBD treatments.

Values (mean \pm standard deviation. $\mathrm{n}=3$ ) followed by different lowercase letter in same column are significantly different $(P<0.05)$.

Brychcy, and Jarmoluk (2013), where cold plasma did not induce pH changes.

The $\mathrm{pH}$ values of the samples submitted to $80 \mathrm{kV}$ at $5 \mathrm{~min}$ were clearly the highest. Furthermore, there was not an apparent relationship between $\mathrm{pH}$ and bacterial growth. $\mathrm{pH}$ has been reported to be a poor indicator of microbial growth and fish freshness (Alfaro, Hernández, Baliño-Zuazo, \& Barranco, 2013). Nevertheless, Senturk and Alpas (2013) specified that fresh Atlantic mackerel with a $\mathrm{pH}$ higher than 7.00 was considered to be spoiled. All treatments tested maintained values under this critical limit.

\subsubsection{Proximate composition}

Moisture and fat content of Atlantic mackerel were found to be in

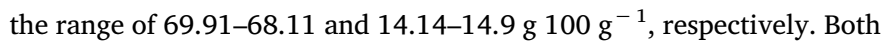
results agreed with previous studies on Atlantic mackerel (Aubourg, Rodríguez, \& Gallardo, 2005; Torres, Vázquez, Saraiva, Gallardo, \& Aubourg, 2013). Fat and moisture content did not change for the treatment conditions employed.

\subsection{Effect of cold plasma on lipid oxidation}

\subsubsection{Fatty acid composition (FA)}

Analysis of fatty acid profiles detected that docosahexaenoic acid (DHA, C22:6 n-3) was the most abundant polyunsaturated fatty acid, and palmitic acid (C16:0) and oleic acid (C18:1, n-9) the main saturated and monounsaturated fatty acids, respectively. This is in agreement with previously reported data (Maestre, Pazos, \& Medina, 2011).

Fatty acids composition of the treated samples was modified by ACP, as shown in Table 1. The levels of oleic acid (C18:1, n-9) and eicosapentaenoic acid (EPA, C20:5 n-3) were lower for the control samples compared to plasma treated samples. These reductions can be attributed to the reactive oxygen and nitrogen species generated and retained within the package.

Polyene ratio also reflected the loss of $\omega 3$ PUFAs (C: 20:5 and C: 22:5) for the control samples. Another study showed that there was no 
Table 1

Main fatty acid composition of Atlantic mackerel submitted different DBD treatments.

\begin{tabular}{|c|c|c|c|c|c|}
\hline & $16: 00$ & $18: 1, n-9$ & $20: 5 n-3$ & $22: 6 n-3$ & Polyene ratio \\
\hline Control & $1.00 \pm 0.00 \mathrm{~d}$ & $0.12 \pm 0.00 \mathrm{a}$ & $0.30 \pm 0.05 \mathrm{ab}$ & $0.91 \pm 0.01 b$ & $1.20 \pm 0.04$ \\
\hline $70 \mathrm{kV} 1 \mathrm{~min}$ & $0.66 \pm 0.01 \mathrm{abc}$ & $0.26 \pm 0.01 b$ & $0.28 \pm 0.03 a$ & $1.00 \pm 0.00 \mathrm{c}$ & $1.95 \pm 0.06$ \\
\hline $70 \mathrm{kV} 3 \mathrm{~min}$ & $0.74 \pm 0.16 b c$ & $0.29 \pm 0.07 b c$ & $0.62 \pm 0.12 c$ & $1.00 \pm 0.00 c$ & $2.27 \pm 0.69$ \\
\hline $70 \mathrm{kV} 5 \mathrm{~min}$ & $0.83 \pm 0.01 \mathrm{~cd}$ & $0.40 \pm 0.00 \mathrm{~d}$ & $0.59 \pm 0.08 c$ & $1.00 \pm 0.00 c$ & $1.91 \pm 0.13$ \\
\hline $80 \mathrm{kV} 1 \mathrm{~min}$ & $0.54 \pm 0.02 \mathrm{a}$ & $0.34 \pm 0.01 \mathrm{~cd}$ & $0.46 \pm 0.03 \mathrm{bc}$ & $1.00 \pm 0.00 \mathrm{c}$ & $2.71 \pm 0.08$ \\
\hline $80 \mathrm{kV} 5 \mathrm{~min}$ & $0.62 \pm 0.04 \mathrm{ab}$ & $0.34 \pm 0.00 \mathrm{~cd}$ & $1.00 \pm 0.00 \mathrm{~d}$ & $0.42 \pm 0.02 \mathrm{a}$ & $2.27 \pm 0.09$ \\
\hline
\end{tabular}

Values (mean \pm standard deviation. $\mathrm{n}=3$ ) followed by different lowercase letter in same column are significantly different $(P<0.05)$.

Table 2

Lipid oxidation markers (Peroxide Value, Dienes) of Atlantic mackerel submitted to different DBD treatments.

\begin{tabular}{lll}
\hline & $\begin{array}{l}\text { PV (meq. active oxygen/kg } \\
\text { lipids) }\end{array}$ & $\begin{array}{l}\text { Dienes (mmol of hydroperoxides/ } \\
\text { kg lipid) }\end{array}$ \\
\hline Control & $6.89 \pm 0.00 \mathrm{a}$ & $1.42 \pm 0.19 \mathrm{a}$ \\
$70 \mathrm{kV} 1 \mathrm{~min}$ & $8.97 \pm 0.74 \mathrm{a}$ & $2.17 \pm 0.28 \mathrm{ab}$ \\
$70 \mathrm{kV} 3 \mathrm{~min}$ & $21.87 \pm 0.59 \mathrm{~b}$ & $2.37 \pm 0.12 \mathrm{~b}$ \\
$70 \mathrm{kV} 5 \mathrm{~min}$ & $35.44 \pm 6.16 \mathrm{c}$ & $2.78 \pm 0.55 \mathrm{~b}$ \\
$80 \mathrm{kV} 1 \mathrm{~min}$ & $17.59 \pm 3.23 \mathrm{~b}$ & $1.46 \pm 0.36 \mathrm{a}$ \\
$80 \mathrm{kV} \mathrm{3} \mathrm{min}$ & $35.75 \pm 0.09 \mathrm{c}$ & $2.25 \pm 0.30 \mathrm{~b}$ \\
$80 \mathrm{kV} \mathrm{5} \mathrm{min}$ & $37.57 \pm 2.49 \mathrm{c}$ & $5.56 \pm 1.33 \mathrm{c}$
\end{tabular}

Values (mean \pm standard deviation. $\mathrm{n}=3$ ) followed by different lowercase letter in same column are significantly different $(P<0.05)$.

significant correlation between total amount of PUFAs and mackerel shelf life in term of oxidation (Maestre et al., 2011).

\subsubsection{Lipid oxidation parameters (PV, Dienes, TBARS)}

Primary oxidation was followed by PV and Dienes assessment (Table 2). Control samples had 6.89 milliequivalents of $\mathrm{O}_{2}$ per kilogram of oil. Ozogul and Balikci (2013) reported similar initial PV. A significant $(P<0.05)$ primary oxidation (PV and Dienes) development was observed for DBD treatment. A comparison of different voltages $(70 \mathrm{kV}$ and $80 \mathrm{kV})$ and treatment time (1, 3 and $5 \mathrm{~min})$ showed both variables increased the rate of oxidation. Similarly, Joshi et al. (2011) suggested that lipid oxidation is proportional to the amount of plasma energy applied. Van Durme, Nikiforov, Vandamme, Leys, and De Winne (2014) also revealed that cold plasma caused the formation of several volatiles related to lipid oxidation. ACP can generate reactive species that have strong oxidation capacities. During DBD treatment, free radicals are generated that trigger lipid oxidation (Kim et al., 2013).

TBARS values ranged from $0.74 \pm 0.01$ to $0.75 \pm 0.00 \mathrm{mg}$ of malondialdehyde (MDA) per kilogram of fish. There were no significant differences $(P>0.05)$ between control and samples submitted to ACP treatment. The effect of ACP on lipid oxidation measured through TBARS values is not clear. Whereas, Rød et al. (2012) and Kim et al. (2013) reported higher TBARS values for plasma treated samples on bresaloa and pork loin, Kim et al. (2011) found lower TBARS values of plasma treated bacon, however this trend reverted over storage. The TBARS values of DBD plasma treated pork and beef samples were unmodified up to a treatment time of 7.5 min (Jayasena et al., 2015).

\subsection{Effect of cold plasma on colour}

Colour has a direct influence on the acceptance of fish and influences consumers' decision to purchase (Rodriguez-Turienzo et al., 2011). The impact of ACP on the colour of Atlantic mackerel is shown in Table 3.

No clear trend was found between any plasma treated conditions, similar to those reported by Rød et al. (2012). However, a significant decrease in $L^{*}$ (lightness) was evident for the plasma treated samples compared to control samples. Kim et al. $(2011,2013)$ also observed that
Table 3

Colour ( $\mathrm{L}^{*}, \mathrm{a}^{*}$ and $\mathrm{b}^{*}$ ) of Atlantic mackerel submitted to different DBD treatments.

\begin{tabular}{llll}
\hline & \multicolumn{2}{l}{$\mathrm{L}^{*}$} & $\mathrm{a}^{*}$ \\
\hline Control & $57.42 \pm 2.15 \mathrm{~d}$ & $3.67 \pm 0.63 \mathrm{ab}$ & $14.12 \pm 2.75 \mathrm{ab}$ \\
$70 \mathrm{kV} 1 \mathrm{~min}$ & $53.72 \pm 2.98 \mathrm{bc}$ & $4.48 \pm 0.33 \mathrm{c}$ & $13.26 \pm 1.56 \mathrm{ab}$ \\
$70 \mathrm{kV} 3 \mathrm{~min}$ & $51.70 \pm 0.50 \mathrm{ab}$ & $3.96 \pm 0.06 \mathrm{bc}$ & $13.21 \pm 0.55 \mathrm{ab}$ \\
$70 \mathrm{kV} 5 \mathrm{~min}$ & $53.87 \pm 1.26 \mathrm{bc}$ & $4.19 \pm 0.29 \mathrm{bc}$ & $15.13 \pm 0.12 \mathrm{~b}$ \\
$80 \mathrm{kV} 1 \mathrm{~min}$ & $55.37 \pm 0.86 \mathrm{~cd}$ & $3.19 \pm 0.35 \mathrm{a}$ & $15.15 \pm 0.42 \mathrm{~b}$ \\
$80 \mathrm{kV} \mathrm{3} \mathrm{min}$ & $50.65 \pm 0.93 \mathrm{a}$ & $4.4 \pm 0.49 \mathrm{c}$ & $13.44 \pm 0.15 \mathrm{ab}$ \\
$80 \mathrm{kV} \mathrm{5} \mathrm{min}$ & $55.91 \pm 0.47 \mathrm{~cd}$ & $3.97 \pm 0.28 \mathrm{bc}$ & $11.52 \pm 2.32 \mathrm{a}$ \\
\hline
\end{tabular}

Values (mean \pm standard deviation. $\mathrm{n}=3$ ) followed by different lowercase letter in same column are significantly different $(P<0.05)$.

the $L^{*}$ value decreased for bacon and pork loin treated with ACP. There were not differences between ACP treated samples and controls for a* and $b^{*}$ values. These results indicated that the ACP did not influence on the colour markedly.

\subsection{Effect of cold plasma on protein structure and water distribution}

NMR provides useful information about the interactions between water and myofibrillar meat proteins (Table 4). Three peaks are thought to be directly related to three water components in muscle tissue. The first component is water closely associated ("bound") with macromolecules $\left(\mathrm{T}_{2 \mathrm{~b}}\right) . \mathrm{T}_{21}$ is immobilised water, which is located in the protein-dense myofibrillar network. The final component is extramyofibrillar water or free water $\left(\mathrm{T}_{22}\right)$. Table 4 shows that water tightly bound to macromolecules $\left(\mathrm{T}_{2 \mathrm{~b}}\right)$ is not influenced by DBD treatment. Similarly, Bertram et al. (2001) demonstrated the $\mathrm{T}_{2 \mathrm{~b}}$ did not reflected any mechanical stress and micro or macro-structural changes in the meat matrix. In all treatments, the majority of water is trapped by the dense myofibrillar network $\left(\mathrm{T}_{21}\right)$. A significant decrease in $\mathrm{T}_{21}$ was however observed for plasma treated samples. This is probably due to the fish structure alteration, which will weaken the matrix that is trapping the $T_{21}$ water. Simultaneously, extramyofibrillar water $\left(T_{22}\right)$ increased as a consequence of the release of trapped water $\left(\mathrm{T}_{21}\right)$.

Table 4

NMR parameters $\left(\mathrm{T}_{2 \mathrm{~b}}, \mathrm{~T}_{21}, \mathrm{~T}_{22}\right)$ area of Atlantic mackerel submitted to different DBD treatments.

\begin{tabular}{llll}
\hline & $\mathrm{T}_{2 \mathrm{~b}}$ & $\mathrm{~T}_{21}$ & $\mathrm{~T}_{22}$ \\
\hline Control & $8814 \pm 3879 \mathrm{a}$ & $331,221 \pm 1466 \mathrm{~d}$ & $10,327 \pm 1573 \mathrm{a}$ \\
$70 \mathrm{kV} 1 \mathrm{~min}$ & $22,221 \pm 1959 \mathrm{~b}$ & $300,835 \pm 3826 \mathrm{c}$ & $10,867 \pm 1562 \mathrm{ab}$ \\
$70 \mathrm{kV} 3 \mathrm{~min}$ & $14,873 \pm 4195 \mathrm{a}$ & $295,586 \pm 1015 \mathrm{~b}$ & $14,576 \pm 2572 \mathrm{c}$ \\
$70 \mathrm{kV} 5 \mathrm{~min}$ & $11,306 \pm 1213 \mathrm{a}$ & $290,037 \pm 8038 \mathrm{~b}$ & $22,705 \pm 3159 \mathrm{~d}$ \\
$80 \mathrm{kV} 1 \mathrm{~min}$ & $12,774 \pm 1033 \mathrm{a}$ & $307,940 \pm 8025 \mathrm{c}$ & $15,586 \pm 2653 \mathrm{c}$ \\
$80 \mathrm{kV} 3 \mathrm{~min}$ & $14,029 \pm 1033 \mathrm{a}$ & $300,017 \pm 1840 \mathrm{c}$ & $13,511 \pm 3111 \mathrm{bc}$ \\
$80 \mathrm{kV} \mathrm{5} \mathrm{min}$ & $0 \pm 0$ & $273,197 \pm 3769 \mathrm{a}$ & $22,685 \pm 870 \mathrm{~d}$
\end{tabular}

Values (mean \pm standard deviation. $\mathrm{n}=3$ ) followed by different lowercase letter in same column are significantly different $(P<0.05)$. 


\section{Conclusions}

DBD is shown to be a potential treatment for reducing the spoilage bacteria (total aerobic psychrotrophic bacteria, Pseudomonas and lactic acid bacteria). Treatment voltage and time were both found to have significant effects on microbial inactivation. Results indicated that ACP caused changes in immobilised $\left(\mathrm{T}_{21}\right)$ and extramyofibrillar $\left(\mathrm{T}_{22}\right)$ water, but no differences were found in water closely associated to molecules $\left(\mathrm{T}_{2 \mathrm{~b}}\right)$. Processing conditions of DBD treatment (voltage and time) rendered the mackerel more susceptible to lipid oxidation. However, ACP does not affect adversely physicochemical parameters such as $\mathrm{pH}$ and colour. Overall, ACP showed promising results in reducing microbiological load of mackerel fish, although lipid oxidation should be further controlled.

\section{Acknowledgements}

Irene Albertos is recipient of a doctoral fellowship awarded by the National Institute for Food and Agricultural Research (INIA).

\section{References}

Alfaro, B., Hernández, I., Baliño-Zuazo, L., \& Barranco, A. (2013). Quality changes of atlantic horse mackerel fillets (Trachurus trachurus) packed in a modified atmosphere at different storage temperatures. Journal of the Science of Food and Agriculture, 93(9), 2179-2187.

Almeida, F. D. L., Cavalcante, R. S., Cullen, P. J., Frias, J. M., Bourke, P., Fernandes, F. A. N., \& Rodrigues, S. (2015). Effects of atmospheric cold plasma and ozone on prebiotic orange juice. Innovative Food Science \& Emerging Technologies, 32, 127-135.

AOAC (1995). Official methods of analysis of AOAC international (16th ed.). Arlington, VA, USA: The Association of Analytical Communities.

Aubourg, S. P., Rodríguez, A., \& Gallardo, J. M. (2005). Rancidity development during frozen storage of mackerel (Scomber scombrus): Effect of catching season and commercial presentation. European Journal of Lipid Science and Technology, 107(5), 316-323.

Bertram, H. C., Karlsson, A. H., Rasmussen, M., Pedersen, O. D., Dønstrup, S., \& Andersen, H. J. (2001). Origin of multiexponential T2 relaxation in muscle myowater. Journal of Agricultural and Food Chemistry, 49(6), 3092-3100.

Bligh, E. G., \& Dyer, W. J. (1959). A rapid method of total lipid extraction and purification. Canadian Journal of Biochemistry and Physiology, 37(8), 911-917.

Bußler, S., Herppich, W. B., Neugart, S., Schreiner, M., Ehlbeck, J., Rohn, S., \& Schlüter, O. (2015). Impact of cold atmospheric pressure plasma on physiology and flavonol glycoside profile of peas (Pisum sativum 'salamanca'). Food Research International, 76(P1), 132-141. http://dx.doi.org/10.1016/j.foodres.2015.03.045.

Chytiri, S., Chouliara, I., Savvaidis, I. N., \& Kontominas, M. G. (2004). Microbiological, chemical and sensory assessment of iced whole and filleted aquacultured rainbow trout. Food Microbiology, 21(2), 157-165.

Dalgaard, P., Gram, L., \& Huss, H. H. (1993). Spoilage and shelf-life of cod fillets packed in vacuum or modified atmospheres. International Journal of Food Microbiology, 19(4), 283-294.

Gram, L., \& Dalgaard, P. (2002). Fish spoilage bacteria - Problems and solutions. Current Opinion in Biotechnology, 13(3), 262-266.

International IDF Standards (1991). Section 74A:1991. International dairy federation. IDFsquare Vergot 41, Brussels, Belgium.

Jayasena, D. D., Kim, H. J., Yong, H. I., Park, S., Kim, K., Choe, W., \& Jo, C. (2015). Flexible thin-layer dielectric barrier discharge plasma treatment of pork butt and beef loin: Effects on pathogen inactivation and meat-quality attributes. Food Microbiology, 46, 51-57.

Joshi, S. G., Cooper, M., Yost, A., Paff, M., Ercan, U. K., Fridman, G., ... 482 Fridman, A. \& Brooks, A.D. (2011). Nonthermal dielectric-barrier discharge plasma-483 induced inactivation involves oxidative DNA damage and membrane lipid peroxidation in 484 Escherichia coli. Antimicrobial Agents and Chemotherapy, 55(3), 1053-1062.

Kim, B., Yun, H., Jung, S., Jung, Y., Jung, H., Choe, W., \& Jo, C. (2011). Effect of at mospheric pressure plasma on inactivation of pathogens inoculated onto bacon using two different gas compositions. Food Microbiology, 28(1), 9-13.

Kim, H., Yong, H. I., Park, S., Choe, W., \& Jo, C. (2013). Effects of dielectric barrier discharge plasma on pathogen inactivation and the physicochemical and sensory characteristics of pork loin. Current Applied Physics, 13(7), 1420-1425.

Kim, J., Puligundla, P., \& Mok, C. (2015). Dielectric barrier discharge plasma for microbial decontamination of dried laver: Effects on physicochemical characteristics. International Journal of Food Science and Technology, 50(12), 2630-2638.

Klockow, P. A., \& Keener, K. M. (2009). Safety and quality assessment of packaged spinach treated with a novel ozone-generation system. LWT- Food Science and Technology, 42(6), 1047-1053.

Maestre, R., Pazos, M., \& Medina, I. (2011). Role of the raw composition of pelagic fish muscle on the development of lipid oxidation and rancidity during storage. Journal of Agricultural and Food Chemistry, 59(11), 6284-6291.

Min, S. C., Roh, S. H., Boyd, G., Sites, J. E., Uknalis, J., Fan, X., \& Niemira, B. A. (2017).
Inactivation of Escherichia coli O157:H7 and aerobic microorganisms in romaine lettuce packaged in a commercial polyethylene terephthalate container using atmospheric cold plasma. Journal of Food Protection, 80(1), 35-43.

Mishra, R., Bathia, S., Pal, R., Visen, A., \& Trivedi, H. (2016). Cold plasma: Emerging as the new stardard in food safety. Research inventy. International Journal of Engineering Science, 6(2), 15-20.

Misra, N. N., Kaur, S., Tiwari, B. K., Kaur, A., Singh, N., \& Cullen, P. J. (2015). Atmospheric pressure cold plasma (ACP) treatment of wheat flour. Food Hydrocolloids, 44, 115-121.

Misra, N. N., Keener, K. M., Bourke, P., Mosnier, J., \& Cullen, P. J. (2014). In-package atmospheric pressure cold plasma treatment of cherry tomatoes. Journal of Bioscience and Bioengineering, 118(2), 177-182.

Misra, N. N., Patil, S., Moiseev, T., Bourke, P., Mosnier, J. P., Keener, K. M., \& Cullen, P. J (2014). In-package atmospheric pressure cold plasma treatment of strawberries. Journal of Food Engineering, 125(1), 131-138.

Misra, N. N., Tiwari, B. K., Raghavarao, K. S. M. S., \& Cullen, P. J. (2011). Nonthermal plasma inactivation of food-borne pathogens. Food Engineering Reviews, 3(3-4), 159-170.

Misra, N. N., Ziuzina, D., Cullen, P. J., \& Keener, K. M. (2013). Characterization of a novel atmospheric air cold plasma system for treatment of packaged biomaterials. Transactions of the ASABE, 56(3), 1011-1016.

Moiseev, T., Misra, N. N., Patil, S., Cullen, P. J., Bourke, P., Keener, K. M., \& Mosnier, J. P. (2014). Post-discharge gas composition of a large-gap DBD in humid air by UV-vis absorption spectroscopy. Plasma Sources Science and Technology, 23(6), http://dx.doi. org $/ 10.1088 / 0963-0252 / 23 / 6 / 065033$.

Moon, A., Noh, S., Moon, S. Y., \& You, S. (2016). Feasibility study of atmospheric-pressure plasma treated air gas package for grape's shelf-life improvement. Current Applied Physics, 16(4), 440-445.

Noriega, E., Shama, G., Laca, A., Díaz, M., \& Kong, M. G. (2011). Cold atmospheric gas plasma disinfection of chicken meat and chicken skin contaminated with listeria innocua. Food Microbiology, 28(7), 1293-1300.

Núñez-Flores, R., Castro, A. X., López-Caballero, M. E., Montero, P., \& Gómez-Guillén, M. C. (2013). Functional stability of gelatin-lignosulphonate films and their feasibility to preserve sardine fillets during chilled storage in combination with high pressure treatment. Innovative Food Science \& Emerging Technologies, 19, 95-103.

Ólafsdóttir, G., Martinsdóttir, E., Oehlenschläger, J., Dalgaard, P., Jensen, B., Undeland, I., ... Nilsen, H. (1997). Methods to evaluate fish freshness in research and industry. Trends in Food Science and Technology, 8(8), 258-265.

Ozogul, Y., \& Balikci, E. (2013). Effect of various processing methods on quality of mackerel (Scomber scombrus). Food and Bioprocess Technology, 6(4), 1091-1098.

Pankaj, S. K., Misra, N. N., \& Cullen, P. J. (2013). Kinetics of tomato peroxidase inactivation by atmospheric pressure cold plasma based on dielectric barrier discharge. Innovative Food Science \& Emerging Technologies, 19, 153-157.

Rød, S. K., Hansen, F., Leipold, F., \& Knøchel, S. (2012). Cold atmospheric pressure plasma treatment of ready-to-eat meat: Inactivation of listeria innocua and changes in product quality. Food Microbiology, 30(1), 233-238.

Rodriguez-Turienzo, L., Cobos, A., Moreno, V., Caride, A., Vieites, J. M., \& Diaz, O. (2011). Whey protein-based coatings on frozen Atlantic salmon (Salmo salar): Influence of the plasticiser and the moment of coating on quality preservation. Food Chemistry, 128(1), 187-194.

Schlüter, O., Ehlbeck, J., Hertel, C., Habermeyer, M., Roth, A., Engel, K., ... Eisenbrand, G. (2013). Opinion on the use of plasma processes for treatment of foods. Molecular Nutrition \& Food Research, 57(5), 920-927.

Senturk, T., \& Alpas, H. (2013). Effect of high hydrostatic pressure treatment (HHPT) on quality and shelf life of atlantic mackerel (Scombers scombrus). Food and Bioprocess Technology, 6(9), 2306-2318.

Surowsky, B., Schlüter, O., \& Knorr, D. (2015). Interactions of non-thermal atmospheric pressure plasma with solid and liquid food systems: A review. Food Engineering Reviews, 7(2), 82-108.

Tappi, S., Gozzi, G., Vannini, L., Berardinelli, A., Romani, S., Ragni, L., \& Rocculi, P. (2015). Cold plasma treatment for fresh-cut melon stabilization. Innovative Food Science \& Emerging Technologies, 33, 225-233.

Torres, J. A., Vázquez, M., Saraiva, J. A., Gallardo, J. M., \& Aubourg, S. P. (2013). Lipid damage inhibition by previous high pressure processing in white muscle of frozen horse mackerel. European Journal of Lipid Science and Technology, 115(12), $1454-1461$

Ulbin-Figlewicz, N., Brychcy, E., \& Jarmoluk, A. (2013). Effect of low-pressure cold plasma on surface microflora of meat and quality attributes. Journal of Food Science and Technology, 52(2), 1228-1232.

Undeland, I., Stading, M., \& Lingnert, H. (1998). Influence of skinning on lipid oxidation in different horizontal layers of herring (Clupea harengus) during frozen storage. Journal of the Science of Food and Agriculture, 78, 441-450.

Van Durme, J., Nikiforov, A., Vandamme, J., Leys, C., \& De Winne, A. (2014). Accelerated lipid oxidation using non-thermal plasma technology: Evaluation of volatile compounds. Food Research International, 62, 868-876.

Vyncke, W. (1975). Evaluation of the direct thiobarbituric acid extraction method for determining oxidative rancidity in mackerel (Scomber scombrus L.). Fette, Seifen, Anstrichmittel, 77(6), 239-240.

Wang, J., Zhuang, H., \& Zhang, J. (2016). Inactivation of spoilage bacteria in package by dielectric barrier discharge atmospheric cold plasma-Treatment time effects. Food and Bioprocess Technology, 1-5.

Ziuzina, D., Patil, S., Cullen, P. J., Keener, K. M., \& Bourke, P. (2013). Atmospheric cold plasma inactivation of Escherichia coli in liquid media inside a sealed package. Journal of Applied Microbiology, 114(3), 778-787. 